\author{
Skrynkovskyy R., \\ Sopilnyk L., \\ Heorhiadi N., \\ Kniaz $\mathbf{5}$.
}

\title{
IMPROVEMENT OF THE MODEL OF THE INNOVATIVE DEVELOPMENT OF THE PRODUCTION SYSTEM OF INDUSTRIAL ENTERPRISES
}

Об'єктом дослідження є особливості формування, використання та розвитку економіко-математичної моделі інноваційного розвитку виробничої системи промислових підприємств (ПП). Однією із основних проблем у сфері моделювання інноваційних процесів та оптимізації процесів розвитку виробничих систем ПП є те, що існуючі економіко-математичні моделі інноваційного розвитку виробничої системи не враховують задачу оптимізації виробничої програми в системі операційного менеджменту. Тут важливе значення має взаємозв'язок контрольних рахунків діграфічного обліку, виходячи з аналізу особливостей виробничих потужностей ПП в системі забезпечення його конкурентоспроможності. В прочесі дослідження використовувалися методи узагальнення, систематизації, системного аналізу, економіко-математичного моделювання та графічний метод. За допомогою цих методів запропоновано систему співвідношень (рівнянь) економіко-математичної моделі інноваційного розвитку виробничої системи ПП $і$ обгрунтовано теоретичні положення. А також систематизовано існуючі рішення та удосконалено практичні рекомендації щодо визначення з допустимих варіантів виробничої програми ПП того варіанту, який задовольняє умови виробництва та оптимізує функцію цілі в системі «витрати - обсяги виробничтва - прибуток». А саме - оптимальне співвідношення обсягу виробництва (реалізаціі) продукиї з витратами і абсолютним фінансовим критерієм розвитку (чистим прибутком) підприємства. З'ясовано, що виробнича система сучасного ПП повинна враховувати концептуальні засади визначення беззбиткового та ефективного обсягів виробництва і складається з 3-х підсистем: підсистеми «інновації, підсистеми «розвиток» та підсистеми «виробництво». Удосконалено економіко-математичну модель інноваційного розвитку виробничої системи ПП, яка грунтується на бізнес-моделі визначення беззбиткового та ефективного обсягів виробництва в системі «витрати - обсяги виробництва - прибуток» на підприємстві. А також враховує задачу оптимізації виробничої програми в системі операчійного менеджменту з урахуванням взаємозв'язку контрольних рахунків діграфічного обліку. Представлені дослідження доцільно враховувати при удосконаленні системно-орієнтованої діагностики та моніторингу діяльності ПП.

Ключові слова: інновачійний розвиток виробничої системи підприємства, виробнича програма підприємства, операчійний менеджмент.

\section{Introduction}

A sufficient level of competitiveness of an industrial enterprise (IE) in a certain market creates conditions for its further development. It is worth noting here that the transition to a qualitatively new level of IE development is impossible without the innovative development of its production system and significant investments, which also leads to the importance of creating and shaping the IE investment attractiveness [1, 2]. At the same time, on the basis of the theory $[1,3,4]$ and the practice of doing business, it was found out that top managers underline the importance and necessity of introducing and building systems of diagnostics of production and economic activities (based on object orientation) on IE. Here, on the basis of operations research [5], management decision-making tasks, models and methods of system analysis, methods of research and optimization of operations using information systems and technologies are important. At the same time, the object of sharp discussions (research) is the features of the formation and use of the economic-mathematical model of the innovative development of the IE production system.
As well as the definition of the acceptable variants of the production program (in the operational management system) of the variant that satisfies the conditions of production and optimizes the objective function (that is, provides the greatest profit). All this led to the relevance of the work and also identified the object of research - features of the formation, use and development of the economic and mathematical model of the innovative development of the IE production system. Therefore, the aim of research is the formation of theoretical positions and the development of practical recommendations for improving the model of the innovative development of the IE production system (based on economic and mathematical modeling), taking into account the task of optimizing the production program in the operational management system.

\section{Methods of research}

In the process of research, the following methods are used: 1. The method of system analysis and economic-mathematical modeling - for the formation (construction) of a system of relations (equations) of the economic and 
mathematical model of the innovative development of the IE production system. Here it is necessary to take into account the conceptual framework for determining the break-even and effective production volumes in an enterprise [6].

2. Methods of generalization, systematization, specification and graphic method - to improve practical recommendations for optimizing the IE production system, taking into account the system analysis [7].

\section{Research results and their discussion}

Studies [6-8] allow to conclude that the production system of a modern IE consists of the subsystems: the «innovation» subsystem, the «development» subsystem, and the «production» subsystem. Thus, the «innovation» subsystem is aimed at searching, researching and creating (developing) innovations - new types of products and/or new (progressive) technological processes. And the «development» subsystem provides the process of implementation (adoption) of innovations. The «production» subsystem ensures the highest possible output of competitive products based on the relationship between the created production capacity and the optimal production program of the enterprise.

So, taking into account the approaches to the construction of economic and mathematical models for optimal functioning and development of production systems [5, 8, 9], let's recommend that the model of the problem of analyzing the innovative development of IE production system be given by the system of relations (1)-(8):

$$
\begin{aligned}
& y_{i n n}(t)=f_{i n n}\left(x_{i n n}(t), v p_{i n n}(t)\right), \\
& \frac{d}{d t}\left(v p_{r z v}(t)\right)=\phi_{12}\left(y_{i n n}(t)\right) \cdot \rho_{12}, \\
& y_{r z v}(t)=f_{r z v}\left(x_{r z v}(t), v p_{r z v}(t)\right), \\
& \frac{d}{d t}\left(\tau p_{p r z}(t)\right)=\phi_{23}\left(y_{r z v}(t)\right) \cdot \rho_{23}, \\
& y_{p r z}(t)=f_{p r z}\left(x_{p r z}(t), v p_{p r z}(t)\right), \\
& x_{i n n}(t)+x_{r z v}(t)+x_{p r z}(t) \leq R(t), \\
& r_{1}+r_{2}+r_{3}=1, \\
& \operatorname{Yopt}_{0}(R(t))=\max _{r 1, r 2}\left(f_{p r z}\left(R(t), r_{1}, r_{2}\right)\right),
\end{aligned}
$$

where $x_{i n n}(t), x_{r z v}(t), x_{p r z}(t)$ - the rate of resources for the subsystems of the IE production system: «innovation», «development», «production», that is, «inputs»; $y_{\text {inn }}(t), y_{r z v}(t)$, $y_{p r z}(t)$ - the rate of «outputs» of the subsystems of the IE production system: «innovation», «development», «production»; $v p_{i n n}(t), v p_{r z v}(t), v p_{p r z}(t)$ - the vectors of the parameters of the functions of innovation, development, production of IE; $f_{i n n}, f_{r z v}, f_{p r z}-$ generalized functions (innovation function, development function, production function); $\phi_{12}, \phi_{23}-$ functions of displaying the output of the previous subsystem (financial and information flows) to the effectiveness of the subsequent subsystem; $\rho_{12}, \rho_{23}-$ the reflection of efficiency gains in the growth of the parameters of the development function («cost-production capacity increase» dependence) of the next element - the formalization of the specificity of a specific innovation - a reflection in the parameter space of the input-output function [8].

The ratio (equations) (1), (3), (5) correspond to the model of the corresponding subsystems of the IE production system «innovation», «development», «production», as technological converters of resources (labor, material, financial, energy [9]). The relations (2), (4) correspond to the model of parametric relations (the influence function «innovation - development», the influence function «development - production»). The ratios (6), (7) are, respectively, the current and normalized limits of the total resource costs. Relation (8) is the criterion and goal of optimization: maximization of the final output of the production system, taking into account the substantive and computational side of the task of optimizing the IE production in the system «costs - production volume profit» $[5,9]$. This is a rather important production aspect in the context of ensuring competitiveness. Control variables $\left(r_{1}, r_{2}, r_{3}\right)$ are the shares of resources for each subsystem $[8,10]$. Thus, the relation $(1)-(9)[5,8,10]$ characterizes the economic and mathematical model of the innovative development of the IE production system. As a result of solving the variation problem (taking into account the time-dependent functions), let's obtain the optimal development strategy based on the development of 3 subsystems of the IE production system: the «innovation» subsystem, the «development» subsystem and the «production» subsystem.

Here (in the model of the task of analyzing the innovative development of the IE production system) the task of optimizing the IE production system (in the operational management system) should include three problem statements (comprehensively), namely [5]:

1) the problem of the optimal distribution of production resources;

2) the problem of determining the optimal technological methods of production;

3) the problem task that takes into account the domestic production consumption of a part of its own manufactured products.

In the context of this, it has been clarified $[5,9]$ that the main goal of solving the problem of optimizing the IE production program (in the operational management system) is determination of the option that satisfies the conditions of production from the permissible variants of the IE production program. It also optimizes the goal function in the «costs - production volume - profits» system. Namely, the optimal ratio of the volume of production (sales) of products with costs and an absolute financial criterion for the IE development (net profit), taking into account the interrelation of control accounts of digraphic accounting (Fig. 1).

In Fig. 1, control accounts of graphic accounting are intended for comparing planned and actual IE activities (revenues, expenses, stocks) for the reporting period. As a result of such a comparison, deviations are detected due to the sales price of products and the efficiency of using IE resources [1, 11].

The presented studies should be taken into account when improving the system-oriented diagnostics and monitoring of the IE operation for the formation and support of management decisions in the organization of labor and production (or in the operational management system). 


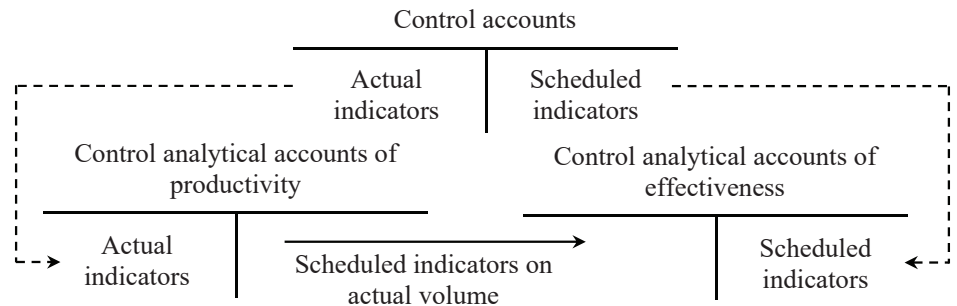

Fig. 1. The relationship of control accounts of digraphic accounting [11]

\section{Conclusions}

According to the research results, the essence of the category «innovative development of the enterprise production system» is clarified. According to the authors of this work, this is the process of IE development through the formation and use of its innovative potential of the production system, the source of which is innovation and innovation processes. These processes are aimed at positive qualitative changes in the state (possibility) of the IE production activity (which is reflected in the improvement of the level of competitiveness, investment attractiveness, etc.). The scientific novelty of the research is improving the model of innovative development of the IE production system, which, unlike the existing ones, is based on the business model for determining the break-even and effective production volumes in the system «costs - production volume - profit» in the enterprise. And also takes into account the task of optimizing the production program in the system of operational management, taking into account the relationship of control accounts of digraphic accounting.

\section{References}

1. Melnyk O. H. Systemy diahnostyky diialnosti mashynobudivnykh pidpryiemstv: polikryterialna kontseptsiia ta instrumentarii: monograph. Lviv: Vydavnytstvo Lvivskoi politekhniky, 2010. 344 p.

2. Skrynkovskyi R. Investment attractiveness evaluation technique for machine-building enterprises // Actual Problems of Economics. 2008. Issue 7 (85). P. 228-240.

3. Kaplan R. S., Norton D. P. Linking the Balanced Scorecard to Strategy // California Management Review. 1996. Vol. 39, Issue 1. P. 53-79. doi: http://doi.org/10.2307/41165876

4. Lynch R. L., Cross K. F. Measure up! The Essential Guide to Measuring Business Performance. London: Mandarin, 1991. 213 p.

5. Karahodova O. O., Kihel V. R., Rozhok V. D. Doslidzhennia operatsii. Kyiv: Tsentr uchbovoi literatury, 2007. 256 p.
6. Break-Even Analysis. Encyclopedia of Production and Manufacturing Management / ed. by Swamidass P. M. Boston: Springer, 2000. 980 p. doi: http://doi.org/10.1007/1-4020-0612-8_100

7. Kono T. Strategy and Structure of Japanese Enterprises. 1984. doi: http://doi.org/10.1007/978-1-349-17627-4

8. Borovska T. M., Severilov P. V., Khomyn Ye. P. Alternatyvni modeli optymalnoho rozvytku vyrobnychykh system v umovakh nevyznachenosti // Systemni doslidzhennia ta informatsiini tekhnolohii. 2014. Issue 4. P. 121-136.

9. Improvement of the express diagnostics of the production activity of the enterprise taking into account the method of determining the optimal production programs in the operational management system / Skrynkovskyy R. et. al. // Technology Audit and Production Reserves. 2018. Vol. 6, Issue 4 (44). P. 4-10. doi: http://doi.org/10.15587/2312-8372.2018.147968

10. Modeliuvannia i optymizatsiia protsesiv rozvytku vyrobnychykh system z urakhuvanniam vykorystannia zovnishnikh resursiv ta efektiv osvoiennia: monograph / Borovska T. M. et. al.; ed. by Borovska T. M. Vinnytsia: VNTU, 2009. 255 p.

11. Holov S. F. Bukhhalterskyi oblik v Ukraini: analiz stanu ta perspektyvy rozvytku: monograph. Kyiv: Tsentr uchbovoi literatury, 2007. 522 p.

Skrynkovskyy Ruslan, PhD, Associate Professor, Department of Business Economy and Information Technology, Lviv University of Business and Law, Ukraine, e-mail: uan lviv@ukr.net, ORCID: http://orcid.org/0000-0002-2180-8055

Sopilnyk Lyubomyr, Doctor of Juridical Science, Doctor of Technical Sciences, Honored Inventor of Ukraine, Professor, Department of Administrative Law and Process, Financial and Information Law, Lviv University of Business and Law, Ukraine, e-mail: sopilnyk012@gmail.com, ORCID: http://orcid.org/0000-0001-6581-7255

Heorhiadi Nelli, Doctor of Economic Sciences, Professor, Department of Management and International Business, Lviv Polytechnic National University, Ukraine, e-mail: nelli.heorhiadi@gmail.com, ORCID: http://orcid.org/0000-0002-8348-5458

Kniaz Sviatoslav, Doctor of Economic Sciences, Professor, Head of Department of Business and Environmental Expertise of Goods, Lviv Polytechnic National University, Ukraine, e-mail: svkniaz@ukr.net, ORCID: http://orcid.org/0000-0002-7236-1759 